\title{
TOURISM DEVELOPMENT MODEL OF THE MINING AREAS FROM THE WESTERN PART OF PETROSSANI DEPRESSION. CASE STUDY: LUPENI TOWN
}

\author{
Ciprian NIMARĂ ${ }^{*}$ \\ University of Petroşani, Faculty of Mining, Department of Environmental Engineering and Geology \\ Petroşani, Romania, e-mail: ciprian.nimara@yahoo.com
}

\begin{abstract}
Citation: Nimară, C. (2019). Tourism Development Model of the Mining Areas from the Western Part of Petroşani Depression. Case Study: Lupeni Town. Analele Universităţii din Oradea, Seria Geografie, 29(2), 158-180. https://doi.org/10.30892/auog.292117-832
\end{abstract}

\begin{abstract}
The present paper aims to suggest some ways of functional and aesthetic rehabilitation of lands affected by mining activity within the western part of Petroșani Depression and especially of Lupeni town. The study wants to show the great potential of these anthropic landforms which can be used for tourism development the area. The landscape is an important resource, being a remarkable natural and cultural heritage that is appreciated for its beauty and aesthetics, but also its contribution to the identity of a region. Beyond how the landscape sheds light on ways of looking at the world, it also confronts us with the issues of nature and how we relate to it. On the other hand, the urban and industrial development forces us to talk about urban landscape, industrial landscape, or technological landscape. The mining landscape from the periphery of Lupeni town can be a subject of touristic development, taking into account the economic problems of the area and the environmental issues made by the the mining activities through time.
\end{abstract}

Key words: landscape, mining, tourism, sterile dump, Petrosani Depression, Lupeni

$$
* \quad * \quad * \quad * \quad * \quad *
$$

\section{INTRODUCTION}

Petroşani Depression is considered a low compartment into the Carpathians, being limited to the North by mountain ranges: Retezat and Şureanu, South and Southeast of Vâlcanului and Parang Mountains. NNE-SSW has guidance about having a length of about $45 \mathrm{~km}$ and a width ranging from East to West between 9 and $12 \mathrm{~km}$. It includes six settlements with their localities: Petrila (Lonea, Jieț, Cimpa), Petroșani (Dâlja, Livezeni), Aninoasa (Iscroni), Vulcan (Dealul Babii, Paroșeni), Lupeni, Uricani (Valea de Brazi, Câmpu lui Neag), with a population in 2011 of 120 734 inhabitants, the largest town beeing Petroșani (37 160 inhabitants). The area of study is a micro-region from Transylvanian Carpathians, traversed by the West Jiu River $(51.4 \mathrm{~km})$ and East

\footnotetext{
${ }^{*}$ Corresponding Author
} 
Jiu $(28 \mathrm{~km})$, whose confluence at the Petroşani (Livezeni) leads to the formation of Jiu River, which forms one of the most beautiful gorges in the country, now designated as a nature park.

The geographical position, hydrological and morphological elements, the landscape, as the entire tourism potential that it possesses a highly recommended as a tourist destination waiting to be fully discovered (Ardeiu, 2004; Nimară, 2011; Nimară et al., 2017; Tofan et al., 2017).

Lupeni town is located in Hunedoara county, at $20 \mathrm{~km} \mathrm{SW}$ from Petroșani, at $700 \mathrm{~m}$, close to Vâlcan mountains. It has an area of 7773 ha and 23390 inhabitants, being considered the third largest town from Petroșani Depression. It borders on the west with Uricani town, on the south with the Gorj county, and in the north, partly with Vulcan town and Baru parish, it is located parallel to the West Jiu river, being guarded by two rows of mountains, which connect the Retezat Mountains with the Parâng Mountains, giving the town an elongated shape (Nimară et al., 2017).

The Lupeni town meets the characteristics of a well-defined geological basin, hydrographic basin and general morphological and geographical depression. According to the shape and position it holds in the relief complex, the municipality of Lupeni, is part of that huge longitudinal corridor, which divides the Southern Carpathians. This is a depression corridor with strong regional accents, which is due not only to the late modeling of the Southern Carpathians, but also to their structure and the tectonic definition of this unit in different geological stages. Considering the settlement of the localities in the depression, differentiation of the climatic elements will be observed in comparison with other regions. The depression character favors the accumulation and stagnation of the cold air, which causes frequent temperature inversions even between the relief units with low altitudes. In summer, the heaters are stronger due to the reduced circulation, so that the daily and annual thermal amplitudes will be different from other regions. The average annual values of air temperature calculated over a period of 60 years have values of $6.8^{\circ} \mathrm{C}$. The monthly average values are between $-4.5^{\circ} \mathrm{C}$ in January and $16.7^{\circ} \mathrm{C}$ in July, so there is an annual amplitude of $21.2^{\circ} \mathrm{C}$. The values of the quite low annual amplitude are due to the frequency of the sea air masses, which in this part is still higher than in other regions, having an open corridor to the west.

The average dates of the first frost appear around October 10, and the frost days disappear after May $1^{\text {st }}$. The average duration of the annual frost-free interval (days with a minimum temperature above $0^{\circ} \mathrm{C}$ ) is $150-159$ days. The absolute humidity of the air, respectively the water vapor, has an annual average value of 6.9, the lowest values being recorded in winter in January, and the highest values, in summer in July. The variation in altitude of the annual average temperature, the amount of solar radiation and the duration of the vegetation season is also reflected in the specificity of the soil processes.

\section{MATERIAL AND METHODS}

The elaboration of the present paper involved the study of the spatial elements and a relational analysis between the anthropic landforms made by the mining activity and the economical and social needs of this part of Petrosani Depression. The data used to carry out this study was obtained from the specific literature and from the field. Also, to achive a better result, I have used landscape design software, named Lands Design 4.6. The results consist in the creation of a 3D model of the future land, being restored according to the social and economic needs of the people living in this area. The proposed model can be an example for mining land restoration which can be used as an alternative, or an additional model to the development of the tourism industry in the Petrosani Depression.

\section{VISUAL ANALYZE OF THE MINING LANDSCAPE FROM THE PERIPHERY OF LUPENI TOWN}

As with any mining operation, the management of the sterile generated by the Lupeni Mining Exploitation has raised some environmental problems. The sterile resulting from the primary extraction and processing of the coal are stored in sterile dumps located in a hilly area, north of Lupeni town, about $2 \mathrm{~km}$ from it (Lupu, 1967). 


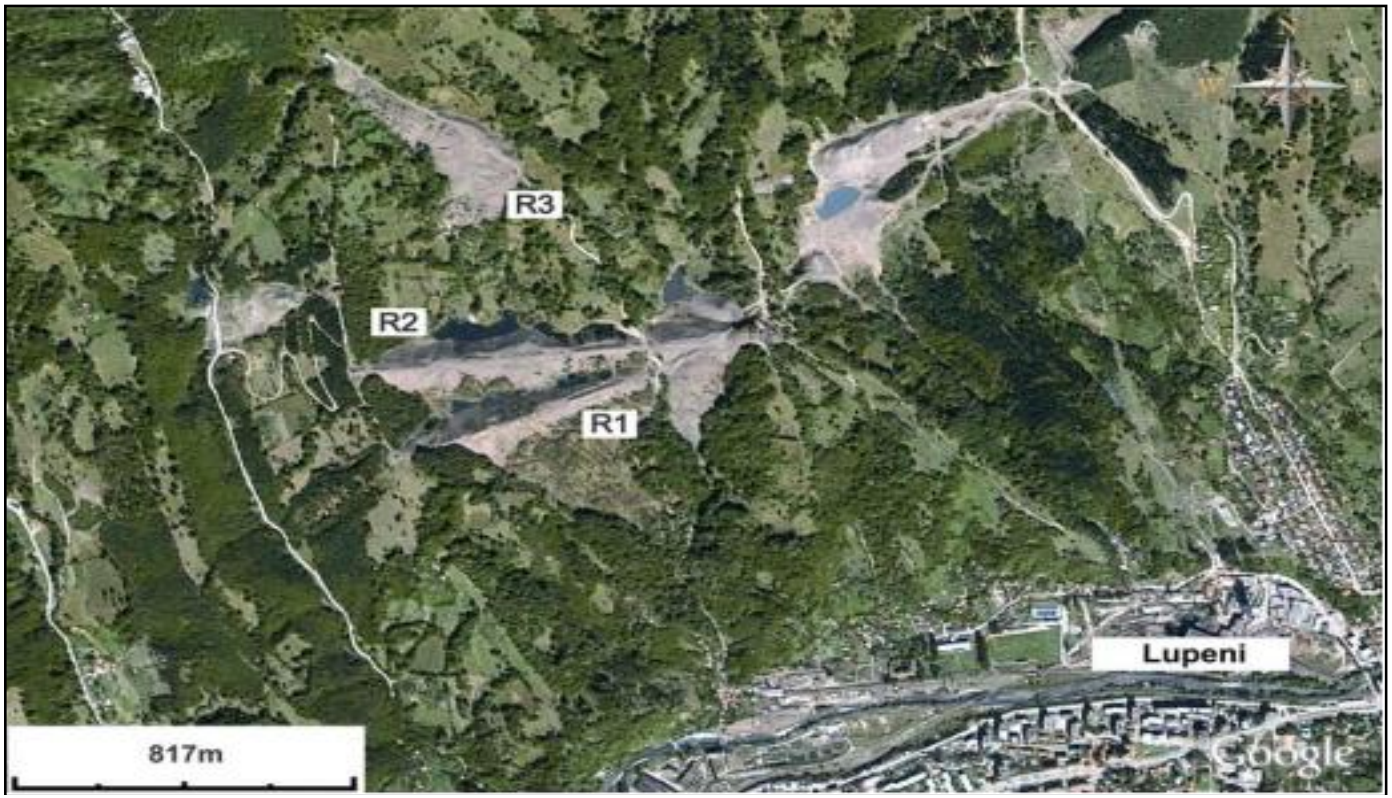

Figure 1. Sterile dumps from the periphery of Lupeni town Hunedoara County (Source: Google Earth, 2019)

In choosing the site, the aim was to affect a small area of land with a low economic importance. The sterile was transported using the funicular, and the storage has been carried out on three branches (denoted by R1, R2, R3) built in a single bench. Of these, only the southern branch (R3) is currently active, the other two being closed (Mitrea, 2000).

The sizes of the branches vary between $900 \mathrm{~m}$ - the R1 branch and $1200 \mathrm{~m}$ - the R3 branch, and their heights between 40 and $70 \mathrm{~m}$. The total surface occupied by the sterile dump is about 34 ha. As a result of the configuration of the deposit, it has exhibited several phenomena of instability over time although at present it is stabilized. The sterile dumps have an obvious impact on the landscape (being visible both from the city and from the slope opposite to the one on which they are located), the morphology and hydrology (the lifting of the dump bodies allowed the formation of lakes by blocking water courses or by accumulating rainwater).

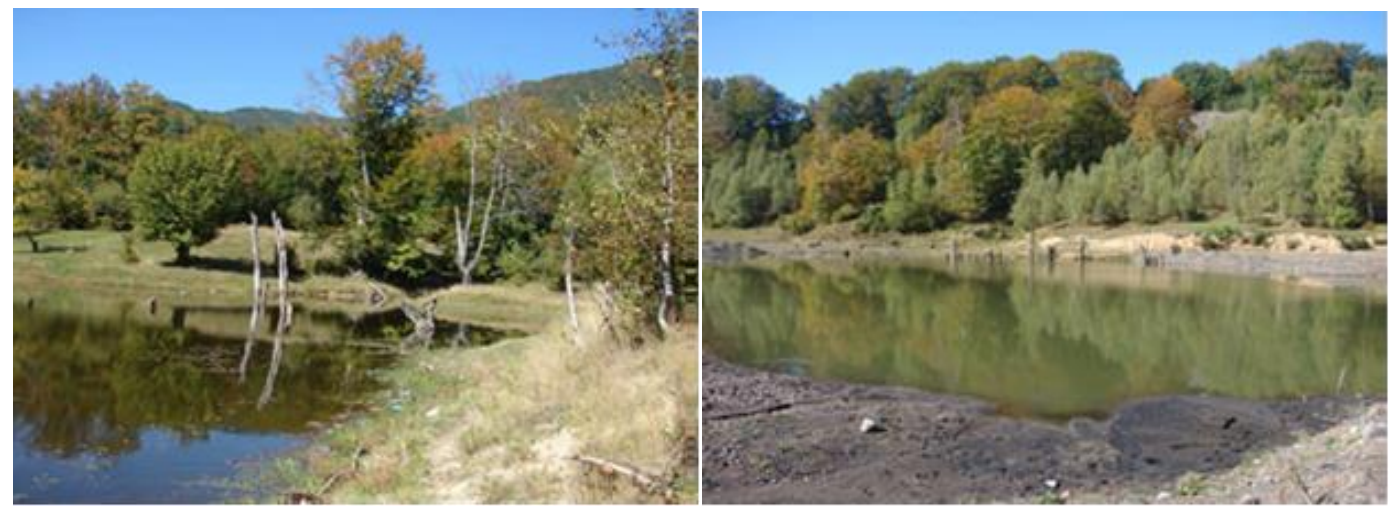

Figure 2. Lakes near the sterile dumps 
Also, the sterile has also changed the state of the ecosystems thus appearing new ecosystems which are poorly developed. They have a high potential for supporting biotic communities and for tourist development (Nimară and Tofan, 2015).

\section{PROPOSED MODEL FOR DEVELOPMENT OF THE MINING LANDSCAPE}

Because mining and related activities have left such an important imprint on the landscape of the Lupeni town, it is necessary to find specific solutions for aesthetic and/or functional reintegration. In order for these solutions to be efficient, suitable and capable of being implemented in this type of territory, it is necessary to take into account it climatic, hydrographic, hydrological and geological characteristics, but also economic and social characteristics. Therefore, in the best case, in order to fade the anthropic imprint it is necessary to design the landscape in such a way that these surfaces are masked with respect to the surroundings until the end of the mining activity, in the case of branch 3. Afforest of sterile dumps involves two procedures, to reclaim and adapt. This model of restoration of an anthropic area is applied in most cases, especially when it does not present a potential for economic recovery, due to the low implementation costs.

As a proposal for the correction of the problems that have been installed on these areas and for a more natural aesthetics, considering their neighborhoods, it is recommended to afforest, in order to create a public park, respectively a holiday village. In addition to the functional benefits that such operation brings (providing a proper microclimate, protection against erosion, regulating the thermal and water regime), there is also the pleasant landscape it creates, in contrast to the current situation. The only disadvantage of this method is the long time required for the development of optimum vegetation and the formation of a vegetative soil substrate.

First of all, for an efficient and sustainable refurbishment it is necessary to perform leveling, consolidation and bank-sloping of the dumps to stop any possibility of producing landslides. With the installation of the soil layer, the sowing and development of grassy vegetation will gradually reduce the degree of infiltration and avoid the formation of acid waters. Later, different species of trees and shrubs can be planted to increase the degree of stability of the anthropic structure. For a normal vegetation development, it is preferred to provide temporary protection by enclosing the sterile dumps. Green represents the living element and must be considered the protection element that has a significant control role in the image of the suburban territory (McHarg, 1995). The status of a living element also results in its dynamic feature in terms of surface area. Even from the appearance of the urban space, the landscape architecture of the town was largely subject to the natural landscape, as also a similar structure can be found in the contemporary town, altered, however, by the social and economic aspects necessary for the coexistence of the human habitat (Hall et al., 2005, Baciu, 2014).

It appears as an asymmetrical element that occurs in the case of the development of forests in the vicinity of the town. The green is built by parks, as the main elements that must have the following location, in the case of the ideal arrangement of the green spaces:

- the largest park must be located in the center of the citadel;

- smaller parks must be connected to the central one and to the urban habitat structures.

The anthropic degraded land, like the one on which the sterile dumps were deposited in the suburban area of the Lupeni town, can be transformed into useful, safe and functional land through a minimum of "greening", with certain special measures, meant to ensure conditions for vegetation. Why minimum, because, in general, nature has begun to regain the surfaces occupied by humans activities, by the appearance of spontaneous species, but also of perennial species.

The land recovery should not be related only to the need of improving the lands degraded by the mining activity in order to return to the initial capacity but more to ensure the subsequent use in various other socially and economically functional purposes, constituting as a necessity of modern society (Crețu et al., 2013; Herman et al., 2016; Moore, 1998; Reid, 2007) (figure 4). 


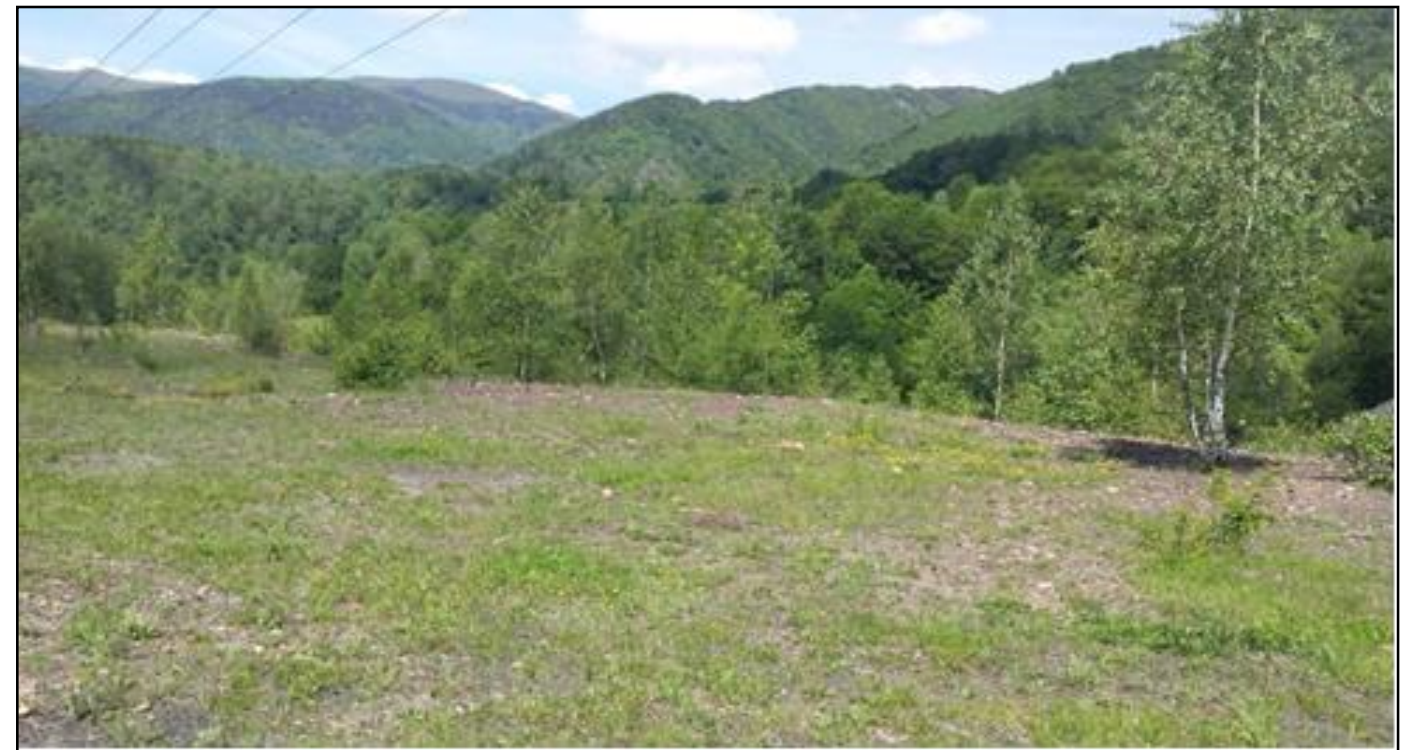

Figure 3. Natural vegetation on the sterile dump

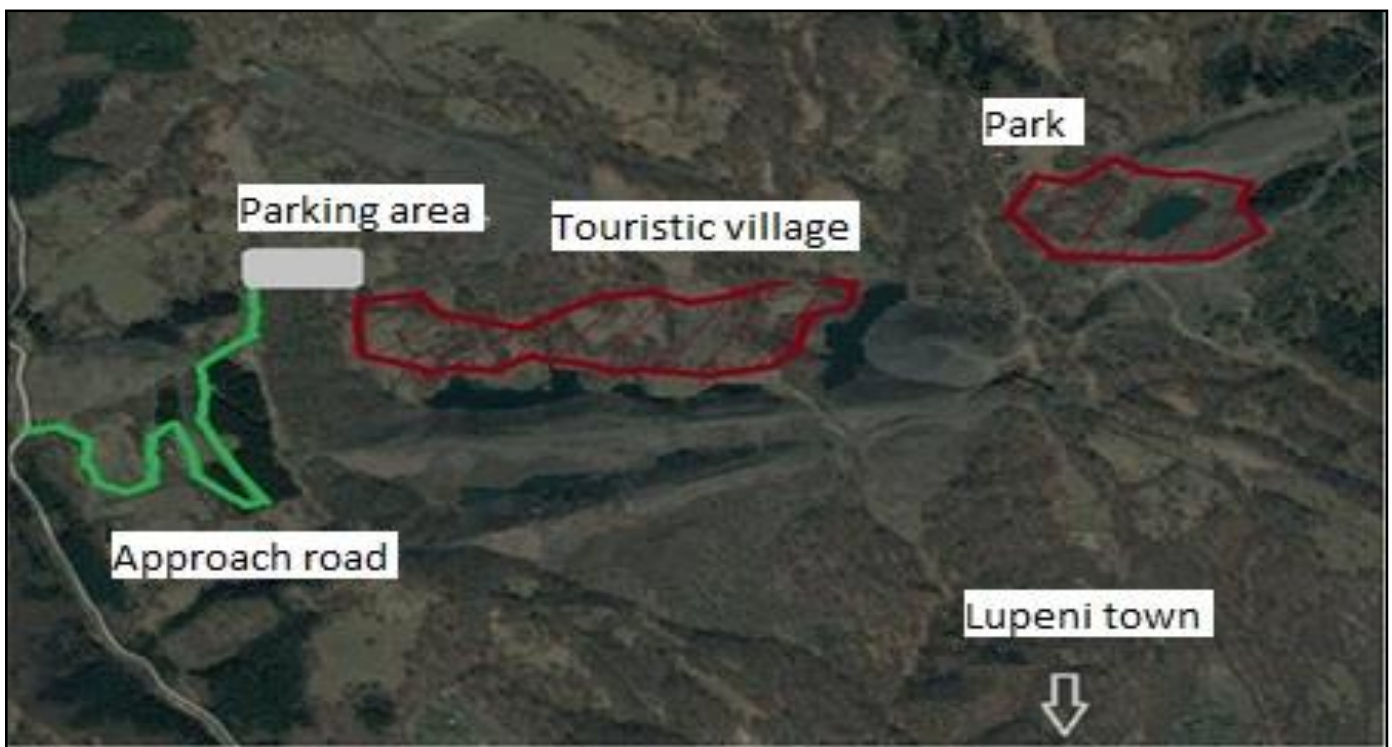

Figure 4. The proposed model

There so, the proposed model to use these anthropic landforms as a base of tourism development where it can be build a touristic village and park (figure 5). The plantations, the grass lawns, the floral decorations, which make up the created anthropic landscape (Buia et al., 2017), want to be integrated into the natural structure of which they are part. All of these are located in a natural landscape rich in vegetation and harmoniously organized, so that the forms of recreation created do not generate functional conflicts (for example, agitation and noise for those who choose for calm and passive relaxation), contributing to the restoration of energy and psychic tonus, necessary for daily activities (Bold and Nimară, 2016). 
On the old sterile dumps were installed birch trees, and in the erosion zones a natural process of consolidation began with "pioneer" species such as the coltsfoot and the white sea buckthorn. On the slopes predominates the birch tree (the age of the most vigorous specimens being about 9-10 years), also sporadic specimens of hazelnut or ash (Cooke and Doomkamp, 1990; Darmer and Dietrich, 2001). On the upper platform of the dump body, which was leveled at the time when it was active, the degree of cover with grassy vegetation is about $50-60 \%$, sporadic specimens of birch, dog rose and even trembling poplar are encountered.
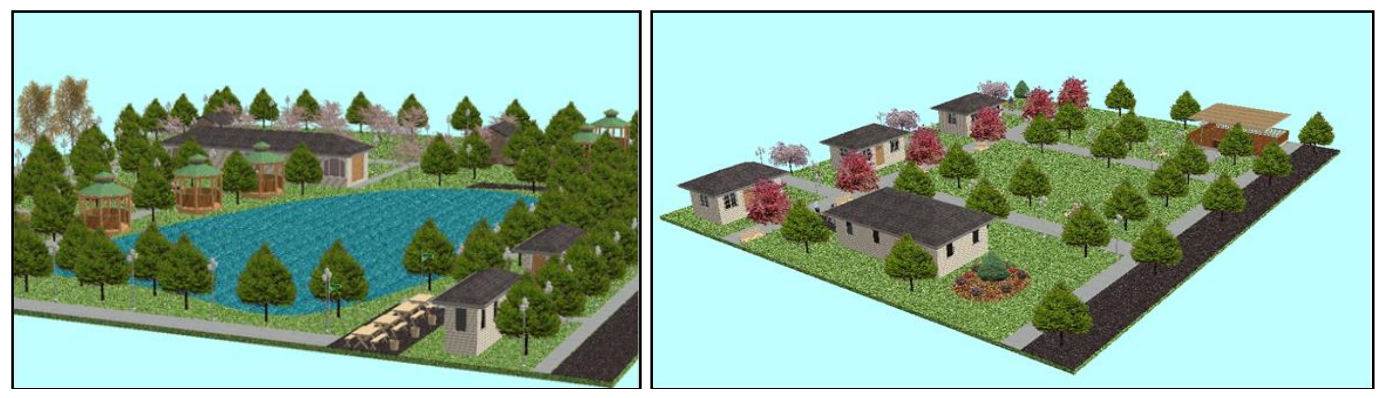

Figure 5. 3D model of the new landscape

In accordance with the type of vegetation encountered on the ground, the plant species I propose to continue the vegetation process is in tune with the bottom lines of the landscape that nature has chosen (waist, structure, texture, color), but also based on soil analyzes. These are: birch, sea buckthorn, pine, willow and different species of grassy vegetation. The ornamental species chosen belong to the category of trees with columnar, tabular and plethora form: bush, juniper, thyme, willow and various species of roses. The chosen size is part of category III, namely, trees with the maximum height between 7 and $15 \mathrm{~m}$. The afforest of the sterile dumps and the land in their immediate vicinity will be carried out on an area of 7.2 ha, being based on the consideration of the height of tree growth, so as to create a uniformity of structure, form and linearity of the landscape. At the base it is recommended to plant the species of black pine, being followed by red pine and wild pine, at distances of $3 \mathrm{~m}, 2 \mathrm{~m}$ and $1.5 \mathrm{~m}$ between trees. The plastic qualities of small shrubs, as individual pieces, can be used especially in the details of the composition, noticeable nearby: on the banks of the lakes, in the rockery, next to rocks and at the bottom of the stairs. The fine foliage, combined with the more aerated branch, gives to the semitransparency silhouettes, effects of light and shadow games (birch, larch, red sea buckthorn); the dense foliage, accompanied by a thick branching, determines a strong contouring of the silhouettes, a complete shielding of the vision and accentuated shadows (linden tree, thyme, box).

In this way is obtained a landscape expressiveness, depending on the growth forms. Viewed from a certain distance, the selected elements can be reflected on the grass carpet, on the gloss of the water, on the sky, on the background of other plantations or on built surfaces (facades of buildings). At the same time, the absence of leaves in the cold season makes the tree architecture more prominent, creating remarkable landscape effects.

\section{CONCLUSIONS}

The "post-industrial land" represents the area used in the past for a certain industrial activity of production, transport or storage which is currently unused or decommissioned and which in the past has played an important role in the economic development of the region.

The mining activity has strongly affected the environmental components of the analyzed area. Despite this, biological, soil and water analyzes showed good quality of terrestrial and aquatic biotic environments. This is due in particular to the relatively high capacity of the sterile dumps to support life forms. In the absence of the ecological rehabilitation measures, the capacity 
of the sterile dumps to reintegrate into the natural circuit can be possible by its location in a hilly area, surrounded by well developed forests, but also by the physical, chemical and biological characteristics it has. The proposed solutions for the landscape reintegration of the suburban area of the Lupeni town have on one hand an aesthetic value, trying to rebuild the degraded landscape after the deposition of the sterile material resulting from the coal exploitation and on the other hand, to offer a note of social and economic functionality to an anthropic degraded land, which didn't have an increased economic value before. At the same time, through the arrangement of this perimeter for tourism and recreational purposes, forest fruits and handmade items can be sell in the touristic village, in specially arranged stands.

\section{REFERENCES}

Ardeiu, M. (2004). Spaţiul geografic al Depresiunii Petroşani [Geographical space of Petroşani Depression]. Teză de doctorat, Universitatea „Babeş-Bolyai”, Facultatea de Geografie, Cluj Napoca (in Romanian).

Baciu, N. (2014). Dinamica şi tipologia peisajului. Note de curs. [Typology and dynamic of lanscape], Editura Bioflux, Cluj-Napoca (in Romanian). Bold, O., \& Nimară, C. (2016). Peisagistică naturală şi antropică [Natural and anthropic lanscape], Editura Universitas, Petroşani (in Romanian).

Buia, Gr., Nimară, C., Tofan, G. B., Bold, O., V., \& Luca, S. (2017). Changes of Petroşani Basin's Landscape as a Result of Coal Mining Activities and Development of the Anthropic Landforms, SGEM 2017, Conference Proceedings, Vol. 17, Section Ecology, Economics, Education and Legislation. Ecology and Environmental Protection, 52: 145-152, Albena.

Cooke, R.U., \& Doomkamp, J.C. (1990). Geomorphology and Environmental Management, Calderon Press, Oxford.

Darmer, G., \& Dietrich, N. (2001). Landscape and surface mining: Ecological guidelines for reclamation, New York.

Hall, M., C., \& Higham, S., E., J. (2005). Introduction: Tourism, Recreation and Climate Change, Tourism, Recreation, and Climate Change (Hall M C, Higham S E J, edit.), Channel View Publications.

Lupu, S. (1967). Procesele şi formele actuale de versant în Depresiunea Petroşani [Processes and present slope forms in Petrosani Depression], Studia UBB, Geologie-Geografie, fasciculus 2: 169-174 (in Romanian).

McHarg, I. (1995). Design with nature, John Willey and Sons Inc. Publishing House.

Mitrea, V. (2000). Peisagistică. Note de curs. [Landscape], Universitatea Tehnică Cluj-Napoca, Facultatea de Arhitectură și Urbanism (in Romanian).

Creţu, C., Herman, G. V., \& Ile, M. (2013). The Impact of the Mining Exploitations from Budoi on the Natural Environment. Analele Universitatii din Oradea, Seria Geografie, 23(1), 73-79.

Herman, G. V., Baias, Ș., \& Măduța, F. (2016). Aspects Regarding the Brownfields from Oradea City, Bihor County, Romania. Brownfields, friches urbaines et recompositions territoriales La durabilité en question, Olivier DEHOORNE, Huhua CAO, Dorina ILIES, PUAG - Publibook, 25 - 40

Moore, C. W. (1998). Water and Architecture/Harry Abrams Inc. Publisher.

Nimară, C. (2011). Cercetări privind reintegrarea peisagistică a arealelor afectate antropic din cadrul bazinului minier Petroşani, Teză de doctorat, Universitatea din Petroşani, Facultatea de Mine, Petroşani (in Romanian).

Nimară, C., \& Tofan, G. B. (2015). The impact of mining activities on the West of Petroşani Depression and identification of affected geomorphological resources. Case study: Aninoasa-Vulcan-Lupeni sector, Studia Universitas BabeșBolyai, Seria Geographia, 60 (2), 27-34.

Nimară, C., Tofan, G. B., \& Luca, S. (2017). Sustainable tourism in Petroşani Depression, Analele Universităţii din Oradea, Seria Geografie, 27 (1), 17-25.

Reid, W. G. (2007). From concept to form in landscape design, J. Wiley \& Sons Publishing House, Canada.

Tofan, G. B., Niţă, A., Nimară, C., Mara, V., \& Peteley, A. (2017). Natural Risks in the Morphohydrographic Bistricioara Basin, Romania, SGEM 2017, Conference Proceedings, Vol. 17, Section Ecology, Economics, Education and Legislation. Ecology and Environmental Protection, 52: 659-666, Albena.

*** (1987). Geografia României III, Carpaţii Româneşti şi Depresiunea Transilvaniei, Editura Academiei RSR, Bucureşti.

*** (2002). Landscape Institute, Institute of Environmental Management and Assessment (I.E.M.A), Guidance for Landscape and Visual Impact Assessment Second Edition.

*** (2010). Development map of the Jiu Valley territory (in Romanian).

*** (2008). Sustainable development strategy of the Jiu Valley micro-region, Local Board of Lupeni Municipality, Hunedoara county, (in Romanian).

*** (2010). The Master Plan for National Tourism Development 2007-2026, World Tourism Organization (in Romanian). www. cniptlupeni.ro, consulted at 12 Octomber 2019.

www. primarialupeni.ro, consulted at 12 Octomber 2019.

www.wto.com “Tourism Vision 2020”, consulted at 12 Octomber 2019.

Submitted:

November 05, 2019
Revised:

November 27, 2019
Accepted and published online

December 18, 2019 